UDK 78.01:004.4

\author{
Nico Schüler
}

School of Music, Texas State University

Fakulteta za glasbo, Državna univerza v Texasu

\title{
Reflections on the History of Computer-Assisted Music Analysis II: The 1960s
}

\section{Razmišljanje o zgodovini računalniške analize glasbe II: šestdeseta leta}

Ključne besede: računalniška analiza glasbe, informacijska teorija, razvoj zgodnjih računalnikov

IZVLEČEK

Drugi v vrsti člankov o zgodovini računalniške analize glasbe se ukvarja z razvojem citirane analize $\mathrm{v}$ šestdesetih letih. Medtem ko razpravlja o razvojno pomembnih pristopih in izdajah, članek ugotavlja, da je vse do konca šestdesetih računalniška analiza bila vse prej kot izčrpna, medosebno povezana ter glede svojih vpogledov bogata. Kljub temu pa je prav bogastvo poizkusov računalniške analize $\mathrm{v}$ šestdesetih letih zagotovilo podlago za bolj poglobljene načine obdelave $\mathrm{v}$ naslednjih desetletjih.
Keywords: computer-assisted music analysis, information theory, development of early computers

\section{Abstract}

This article, the second in a series of articles on the history of computer-assisted music analysis, focuses on developments of computer-assisted music analysis during the 1960s. While the most trendsetting approaches and publications are being discussed, this article points out that at least up to the end of the 1960s, computer-assisted analysis of style was anything but comprehensive, interpersonal, and rich in musical insight. Nevertheless, the wealth of attempts to analyze music with the help of computers during the 1960s provided the foundation for the deeper approaches to computer-assisted music analysis of the following decades.

\section{Introduction}

This article is the second of a series of articles on the history of computer-assisted music analysis. The introduction of the first "part" of this series (Schüler 2005) pointed out that computer-assisted music analysis, which emerged about 50 years ago, provides analytical tools that help solve problems, some of which may be unsolvable with- 
out the assistance of the computer. Unfortunately, most research in the area of computer-assisted music analysis has been carried out, again and again, without any explicit review of preceding attempts and accomplishments. Even the most recent research bears traces of two fundamental flaws that have plagued most research carried out to dates: there is no classification of analytical methods within a comprehensive historical framework, and there is no critical evaluation of those methods.

This series of articles will attempt to solve the main problem related to these flaws: to provide a historical account and framework of methods of computer-assisted music analysis. The source materials for the historical account consist of nearly 2,000 published and unpublished writings, including dissertations and internal research papers from many countries, which were collected and analyzed over many years.

This specific article ${ }^{1}$ focuses on developments of computer-assisted music analysis during the 1960s, while the first real computer-application date as far back as 1955 (see ibid.): a team around the mathematician Frederick P. Brooks developed an analysis-synthesis-approach, in which Brooks et al. derived the compositional rules automatically. As such, the project by Brooks et al. (1957) was the only completed project of computer-assisted music analysis of the 1950s, although Lejaren Hiller $(1962,1964)$ developed ideas that gave directions - for several of his students as well as others (see below) - for the more sophisticated approaches to computer-assisted music analysis of the 1960s.

\section{Computers and Computing during the 1960s}

Most important for the history of computer-assisted music analysis is the development of computers and computing in general. A few comments on the developments in this area are therefore necessary.

Already soon after World War II, IBM established itself as one of the leading makers of calculators and eventually computers. In the early 1960s, IBM continued with a standardization process to achieve compatibility among all their computer components as well as their software components. The result was their System/360 (1964). However, programming turned out to be more costly than the hardware itself. Further developments were fully integrated circuits, giant number-crunching computers, and time-sharing computer systems (which allowed more than one user to execute programs concurrently).

The US-military had also played an important role in the emerging computer industry since World-War II. For their needs, the idea of real-time computing for a flight simulator at the Massachusetts Institute of Technology (MIT) was most important. For the purpose of real-time computing, computers with a much higher speed and a much higher reliability were needed than existing technology had to offer. Important developments were the core-memory, printed circuits, mass-storage devices, and CRT-graphi-

Explanations of the basic terminology used in this article and definitions of commonly used terms in this area of methods of computer-assisted music analysis can be found in Schüler 2005. 
cal displays. Military projects also provided a 'platform' for further developments in software engineering.

The first large civilian real-time project was the airline reservation system SABRE (Semi-Automatic Business Research Environment) in the 1950s and early 1960s, and the Universal Product Code (UPC) in the early 1970s. First scanners were manufactured by IBM and NCR. These developments were of great economic importance: the whole manufacturing-distribution network became involved in electronic data tracking and automatic ordering, etc.

While in the early 1950 s software was still supplied at no additional cost by the computer manufacturer, 'software contracting' soon developed: Corporations, such as the System Development Corporation (SDC), emerged. In the early 1960s, the software industry was booming. However, in the late 1960s, a software crisis emerged because of the much faster growing hardware industry and the incapability of exploiting the new hardware effectively (since large programs were needed). It took many years before programming became a real engineering discipline with its "structured design methodology" and its development model as an organic process which would never really be 'finished'. The concept of 'software packages' emerged in the late 1960s; these packages were much more cost-effective than custom software. At the same time, large computer manufacturers decided to price their software and hardware separately. While computers and computing became an important factor in the industry and in the military, research applications in music were very limited in the 1960s with regard to the availability of computers at large universities and with regard to their limited computing capabilities.

\section{Computer-Assisted Music Analysis in the 1960s}

Available hardware severely restricted the computer applications of the 1960s. However, early applications of statistics and of information theory to music analysis especially in the US - as well as music-philosophical reflections (see Schüler 2005) especially in Europe -, spurred the boom of computer-assisted methods of music analysis. To show specific tendencies of those methods, some trendsetting applications will be discussed.

In his studio for experimental music at the University of Illinois, Lejaren A. Hiller collaborated in several analytical research projects. Three of these projects are described in Hiller 1964. ${ }^{2}$ The first project (Bean 1961; see also Hiller and Bean 1966) involved a comparison of four sonata expositions (by Mozart, Beethoven, Hindemith, and Berg), mainly based on first-order entropies of pitches and intervals as well as on the "speed of information" (i.e., of entropy), which was calculated via note density and tempo. But while Bean's project was not computer-assisted, Baker's research (Baker 1963 ) - the second project mentioned in Hiller 1964 - was partly carried out with the assistance of ILLIAC, the first electronic computer at the University of Illinois. ${ }^{3}$ Thus,

There, Hiller gives the impression that those projects were mainly his own research projects. However, he rather collaborated in the dissertation research of his students Calvert Bean (1961), Robert A. Baker (1963), and Ramon C. Fuller (1965).

However, exactly how the computer was used was not described in Baker's dissertation. 
this study is the first dissertation project in the area of computer-assisted music analysis. Modulation-free passages of 16 string quartets by Mozart, Haydn, and Beethoven were analyzed with regard to transition probabilities of harmonies and of pitches as well as their relationships. ${ }^{4}$ Finally, the third project discussed in Hiller 1964 (Fuller 1965; see also Hiller and Fuller 1967) involved the analysis of the first movement of Anton Webern's Symphony op. 21. Here, entropy and redundancy calculations (of higher orders) of pitches and intervals revealed, among others, the formal structure of the piece.

William J. Paisley chose a quite different approach to computer-assisted music analysis. Based on communication theory, Paisley (1964) made a fundamental contribution to identifying authorship (and with it, stylistic characteristics) by exploring "minor encoding habits", i.e. details in works of art (which would be, for instance, too insignificant for imitators to copy). ${ }^{5}$ To take an example from a different field, master paintings can be distinguished from imitations by examining details like the shapes of fingernails. Similarly, Paisley showed that there are indeed significant minor encoding habits in music. He analyzed note-to-note pitch transitions in the first six notes of each of the 320 themes by Bach, Haydn, Mozart, Beethoven and Brahms. He chose the parameter 'pitch', because pitches can be easily coded for computer processing and because some research on tonal transitions had already been reported.

In his first analysis ${ }^{6}$, Paisley calculated interval frequencies of up to six semitones within the first 6 notes of two 160-theme-samples. Furthermore, he calculated the Chi Square Test for Goodness of Fit of those interval distributions for the two samples. While these results could not significantly distinguish Haydn, Mozart, and Beethoven, Paisley claimed a successful distinction between these composers with his second analysis, in which he calculated frequencies and chi squares of two-note transitions between the classes tonic, third, fifth, all other diatonic tones and all chromatic tones. In both analyses, the results of the chi square test were then compared with results from "unknown samples" (Mozart, Beethoven, Händel, and Mendelssohn). The results from analyzing themes by Mozart and Beethoven could (in the second analysis) be successfully matched with the "known" Mozart- and Beethoven-samples, while Händel and Mendelssohn were significantly different. But even though only a modest amount of data was involved in this investigation, and even though a reduction of the number of possible intervals to seven (based on inversions as well as on neglecting the direction) seems to be questionable, Paisley's study was well documented and its results were, considering the time of the study, very impressive. Several other authors referred later to Paisley's approach.

In 1969, Stefan M. Kostka wrote a set of FORTRAN-programs ${ }^{7}$ for analyzing string quartets by Paul Hindemith" , following William J. Paisley's definition of "minor encod-

\footnotetext{
However, the harmonic analysis itself was done traditionally, not computer-assisted.

For a general discussion on this topic, especially with regard to text analysis, see also Paisley 1969.

Paisley performed the analyses on the Stanford University 7090 computer.

These programs were implemented on a CDC 3600 computer.

The music was coded in ANON, an alphanumeric coding system developed in the course of a seminar at the

University of Wisconsin, conducted by Roland Jackson. Since the code originally remained unnamed and untested, Kostka named it for his study. See Kostka 1969, $112 \mathrm{ff}$.
} 
ing habits". His task was "to test the hypothesis that Hindemith's style shows a consistency in his use of certain 'hidden communicators' of which Hindemith himself may or may not have been aware. On the other hand, since Hindemith's style did not remain unchanged throughout his life, it was considered worthwhile to see if his employment of some of these communicators showed a noticeable and consistent change from the early quartets to those written in the 1940s." (Kostka 1969, 173) Kostka analyzed roots and classes of chords ${ }^{9}$, treating each vertical event equally (regardless of their duration or regardless of whether they contained non-harmonic tones etc.). In his explanations, Kostka referred to Gabura (1965), who found - analyzing music by Brahms and Bartók - only small differences in the result of weighting chords by frequency as opposed to weighting chords by duration. Kostka tried to verify this for Hindemith's music on the example of the first movement of his Fifth String Quartet ${ }^{10}$ by letting the computer calculate frequencies and percentages of chords. Other algorithms counted frequencies of all chords (both by treating inversions as independent chords and by dealing with "normal forms") and their harmonic contexts. Finally, in horizontal analyses, various kinds of melodic intervals were calculated ${ }^{11}$, and the program searched for melodic patterns that had been defined by the analyst, including permutations. Even though Kostka found stringent regularities in the interval frequencies and frequencies of chord classes in all quartets, one can hardly interpret these distributions as "Hindemith's melodic style" (Kostka 1969, 263); analyses of other genres used by Hindemith or other quartets by other composers would be necessary for a verification. The inconsistencies Kostka found in other analyses (e.g. root movements, tonality, etc.) led to the conclusion that either those characteristics are not important for Hindemith's style or the analytical method would need to be modified.

Kostka's study (1969) also showed a limitation of his computer-aided approach to music analysis: the enormous volume of data (the huge number of punched cards) made it impossible to extract, examine, and compare the data "for every theoretical question that came to mind" (ibid., 250). But Kostka's dissertation is very important in so far as it is based on the study of former approaches as well as on ('traditional') music-theoretical and musicological writings pertaining to the style in the music by Paul Hindemith. Some 'traditional' explorations of Hindemith's style could be verified by Kostka's computer-aided study.

The possibility of quickly processing a large amount of data with new computer techniques was recognized in the 1960's, especially by US-scholars in musicology and music theory. In 1966, Gerald Lefkoff (1967a) and Allen Forte (1967a) addressed this topic at the "West Virginia University Conference on Computer Applications in Music". Forte gave 'good' reasons for applying the computer to music analysis: "The com-

\footnotetext{
Here, the definition of "roots" and "chords" goes back to Hindemith's theoretical system itself, described in Hindemith 1945, $94 \mathrm{ff}$. Another system of chord classification, which Kostka applied, was based on the distinction between Intervallic, Tertian, Quartal and Whole-Tone chords.

10 The number of pieces for such verification remained certainly questionable.

11 These included: A) every single interval; B) minor with major intervals combined; C) minor with major and their inversions combined (e.g. descending second and ascending seventh); D) all inversions combined: all seconds with all sevenths etc.; E) intervals with their mirror inversions combined (minor seconds up and down, major seconds up and down, etc.); F) all major and minor seconds, all major and minor thirds, etc., combined.
} 
puter can be programmed to deal with complex structures - such as musical composition - very rapidly. ... A second reason for using the computer derives from the requirements of completeness and precision that form the basis of every computer program. .. . The design of an algorithm, the formulation of a decision-structure to solve a problem, the careful checking out of a malfunctioning program - all these activities provide clarifications and insights which would be difficult, perhaps impossible, to obtain otherwise." (Ibid., 33-34.) Without going into details, Forte also described a computer project ${ }^{12}$ for the (set theoretical) determination of similarities and differences of sets, for the interpretation of those with respect to characteristics of the environments in which they occur, and for the design of a structural model in terms of set-complex theory (ibid., 39). ${ }^{13}$ Gerald Lefkoff (1967b), on the other hand, described a system "for the study of computer-residing, score-derived musical models" (ibid., 45). Written in FORTRAN, Lefkoff's 'model' saved musical information in time-indexed arrays: pitch, rhythmic values, vocal text, figured bass symbols, dynamics, articulations, and editorial comments. Lefkoff then extracted, along with data relating to other relationships, "a complete list of melodic fragments from a group of compositions, with frequency distribution data for the fragments within each composition and ... [then] compare[d] the relative frequency of occurrence of each fragment in selected groups of compositions." (Ibid., 55.) The value of Lefkoff's model can be seen in its ability to generalize such analytical procedures and thereby discover stylistic trends. However, Lefkoff did not describe any concrete analyses; and thus, it is questionable if his theoretical model was indeed functioning and reaching the envisioned goals.

Milton Babbitt (1955, 1960, 1961), with his analytical approaches to dodecaphonic and set structures, was of outstanding importance for music theoretical developments in the US. His research provided the basis for the manifold (US-) discussions on the use of logic-mathematical procedures in music analysis (and likewise in composition). Since the mathematical part in set theoretical analyses is very suitable for implementations in computer programs, many computer applications in music theory and musicology after the mid 1960s (Babbitt 1965) are related to set theory.

Donald M. Pederson (1968), for instance, described a computer-assisted, analytical project that used set theoretical and statistical approaches. After the transformation of the musical data (contained in the scores) into a suitable code for music analysis ${ }^{14}$, a program computed subset and superset relations of a given set within the score. All set types found were also examined with regard to interval vector and number of occurrences. Finally, another program computed frequencies of pitch classes and generated graphic displays that showed pitch patterns within specific voices and showed the interaction between them; it also found instances of fixed registration, found other pitch patterns, and displayed the registral use of each pitch-class. Pederson analyzed Anton Webern's string quartet op. 28 in two ways: at first, 'traditionally' "to provide a

\footnotetext{
His set of computer programs was written in MAD.

A similar program, written in the computer language SNOBOL 3, was described in Forte 1966.

Pederson used the "Ford-Columbia Digital Alternate Representation of Musical Scores" (DARMS), which was developed by Stefan Bauer-Mengelberg. Since this code was not specifically developed for music analytical investigations, Pederson modified it slightly. See Pederson 1968, especially pp. 5-16.
} 
description of the structure and the use of the twelve-tone set and to establish the formal sectioning of the composition" (ibid., 73), and then, after this contextual analysis, non-traditionally, using a computer-aided analysis of the harmonic content applying the methods described above. Pederson concluded, that "even though the two approaches examine different aspects of the music, the relationship found between sections in the contextual analysis are born out by the result of the computer processing" (ibid., 75). Even though the weaknesses of Pederson's approach were the - more or less unexplained - segmentation of the score by the program (to find subsets or supersets of the one set which was identified by himself) and the use of only very basic statistical measurements, Pederson did not only combine traditional and computer-aided analysis in general, but also set theoretical and statistical approaches.

In 1970, Allen Forte (Forte 1970a, 1970b) described two computer programs: one calculated set complex relations, and the second program calculated set class memberships for arbitrary sets of pitch classes.

A pilot study that began as an attempt to automate the collection of bibliographic data from five percent of the 17th century chanson repertory (about 300 pieces) by Lawrence F. Bernstein and Joseph P. Olive (1969) ended up as a computer-assisted project in stylistic analysis. ${ }^{15}$ Eleven types of stylistic data were calculated, each falling into one of the three categories: routine analysis, statistical analysis, and numeric representation. While routine analysis included standard harmonic analysis (determination of the roots of all triads) ${ }^{16}$, measurement of the rate of harmonic rhythm, and determination of the range of the vocal parts, the statistical calculations - also designed to aid in harmonic analysis - were directed at the number of relatively strong or weak root movements, the degree to which inversions were used, the ratio of complete and incomplete chords, and the frequency of recurrent harmonic adjacencies (Bernstein and Olive 1969, 158). Numeric and graphic representation involved ascertaining textural complexity by analyzing the interaction of several (weighted) parameters of style (number of voices, the amount of coordinated rhythmic activity among the voices, the number of separate rhythmic attacks across the polyphony, duration of the notes; ibid., 159). The authors also expressed the need for improving the computer program for further research: The program should determine more than just the roots of complete triads and it should also distinguish between structural and ornamental harmonic motion.

Astonishing for such a project in the 1960s was the (positive) reservation towards the possibilities of using computers for analyzing music: The authors were never "deluded into believing that the computer was in any way capable of analyzing a piece of music. Rather, we used the information made available by the computer as a means of substantiating or explaining the insights into a given composition that we gained by

15 For the music representation of this project, the Chicago Linear Music Language was developed, which especially takes notational necessities of the 16th century chanson into account. The program was written in FAP for an IBM 7094 computer.

16 "In the performance of harmonic analysis, the chords had to be examined each time a note changed in any of the voices. A chord was rejected for either of the following reasons: (1) if it contained less than three notes; or (2) if it included intervals other than thirds and fifths. If neither of these conditions prevailed, the root of the chord was determined by examining the intervals, concentrating on the interval of the fifth, and designating its lower member the root." Ibid., 159. 
means of a direct confrontation with the music." (Ibid., 160) ${ }^{17}$ Thus, the analyses were indeed 'only' computer-assisted! The information, which was electronically derived, was only 'helpful' for setting up stylistic profiles of the composers. Even though all analytical operations could have been done without the assistance of a computer, the compilation of the statistical data would have taken too much time to be considered feasible. (See ibid.)

Michael Kassler (1966) developed a special-purpose programming language named MIR - an acronym for "musical information retrieval". Since MIR is both a programming language and a language for musical information retrieval, music theoretical functions are directly expressible within the program; at the same time, the program functions as an evaluation tool. MIR was usually used in connection with the IML (Intermediate Music Language) music code. As such a connection between music code and information retrieval language, the acronym IML-MIR was used. ${ }^{18}$

Arthur Mendel (1969) applied, together with Lewis Lockwood ${ }^{19}$, the IML-MIR system to the analysis of the style of Josquin des Prez. This included primarily calculations of frequencies of all simultaneities. ${ }^{20}$ Using the ratio between the percentages of all the four-part simultaneities that constitute complete triads and the percentages of complete triads, Mendel tried to show that one mass subsection was not composed by Josquin des Prez, as scholars originally assumed. However, the main problem with Mendel's project was the machine-dependent implementation: Because the author had to switch computers, the project could not be continued as planned.

Maurita P. Brender and Ronald F. Brender (1967) developed a program for the transcription and analysis of the Bamberg Codex, notated in Franconian notation. The digital representation of the music included pitch and tone duration. The output of the transcription program, punched cards, was used as input for the analytical programs. ${ }^{21}$ The analyses focused on occurrences of part or voice crossing ${ }^{22}$, on melodic intervals in each part, on the "average rate of movement" ${ }^{23}$, and on vertical intervals occurring in the three positions: strong, weak, and off beats. The output of the program also included a graphic description of the chord usage in every piece. With regard to existing theories of musical practice of the Middle Ages (and specifically, during the time of the Bamberg Codex), Brender and Brender tried to verify traditional assertions, concerning the usage of consonances and dissonances. ${ }^{24}$ In addi-

17 It continues: "In this way, the data supplied by the computer proved to be very useful in explaining why a particular portion of a chanson generates a sense of tension, while another section of the same piece creates a feeling of rest." Ibid. For a relatively detailed introduction see Robison 1967.

19 Lockwood already presented a progress report on this project at a "Musicology and the Computer I" conference in 1965 (see Brook 1970a), which was published five years later (Lockwood 1970).

20 Future plans included calculations of interval frequencies and of correlations between the primary accent of a Latin word and the duration of the note set to the syllable that is immediately following. See Mendel 1969, 51.

21 Bur here, only five motets with Portare tenors from the Bamberg Codex were analyzed.

22 Thus, parts of the analyses were aimed at the determination "to what extent the motets, tenor, and triplum could be associated with a fixed position in the cord structure" (ibid., 206).

23 "Each melodic interval is divided by the duration of the first note of each pair and the average taken over the whole melodic line." (Ibid., 206.) A surprising result was that decreasing intervals were used more commonly than increasing intervals, i.e. "that descending lines tend to change or move faster and over larger intervals than ascending lines. The motetus was normally the most negative, followed by the triplum, then the tenor." Ibid.

24 Even though, the assertions could be verified, "the most general fact... is that the number of exceptions is considerable. In particular, the assertion that a consonance should begin every perfection is, at best, true only in a simple majority of cases." Ibid., 207. 
tion to the analytical attempts, a formal (context free and only right branching) grammar of Franconian notation was formulated. Successful translations (transcriptions) verified the grammar.

Benjamin Suchoff selected transcriptions of Bartok's Serbo-Croatian Folk Songs (a small collection of 75 women's songs) as a pilot project for lexicographical orderings by computer. After dividing and numbering the melodies in accordance with Bartók's determination of the content structure in every melody section, and after coding ${ }^{25}$, the computer extracted string interval sequences ${ }^{26}$ coded as sequences of positive and negative integers, and sorted and compared the derived sequences. ${ }^{27}$ This made further statistical analyses possible. However, in several short articles (Suchoff 1967a, 1968a, 1968b, 1969, 1970a), the analytical part was mentioned only briefly and only the indexing approach was described in detail. The purpose of using the computer for the analysis remained unclear, at least with regard to the identification of melodic variants, since they were probably realized 'traditionally'. Only in Suchoff's 1968a article, the "machine analysis of a string content for frequency occurrences" (ibid., 6) is mentioned, but without further details. Later, Suchoff (1969) suggested the use of 'skeleton models' in the search for variants and orders. In the explanation of a melodic skeleton, Suchoff referred to Bartók; but it remains unclear in Suchoff's writings if the skeleton models were actually derived with the computer or by hand. In Suchoff 1970a, some analytical results were included, e.g., prevalent types of identical interval sequences, interval frequencies, and frequencies of phrases with a certain interval structure. Suchoff's research certainly provided an important impulse for folksong research on the American continent.

Richard E. Joiner (1969) conducted comparative analyses of eleven Gregorian chants from the early period (approximately 600-1000 A.D.) and twelve from the late period (approximately 1000-1300 A.D.). His analyses were based on frequency counts and relative frequencies of the notes, intervals, and phrases, and on the average length of phrases per chant. The computer program also examined each chant for repeated patterns with the length of two to eight notes. Even though the results - in general formulated by the author himself - 'sounded' characteristic of the music, ${ }^{28}$ the standard deviations of all results were too large for a computational model of authentication based on the statistical calculations mentioned above. Furthermore, no validity check was described in Joiner's paper.

In Europe, Roland Mix (1967) extended Wilhelm Fuck's methods of entropy analysis (see Schüler 2005). Having chosen the first movement of Haydn's string quartet, op. 76 No. 3, and the first movement of Schoenberg's third string quartet, op. 30, Mix analyzed entropy dependencies of higher orders of pitches, harmonies, dynamics and

25 The calculations were executed by an IBM 1130 computer (Suchoff 1967a), later by an IBM 360 computer (Suchoff 1968). Most programs of this project were written in FORTRAN, some in PL/1, and the music was encoded in the Ford-Columbia code. The indexing system was devised by Harry B. Lincoln (see Lincoln 1967a, 1967b, 1968a, 1968b, 1969a, 1969b).

26 Repeated notes, interval quality, and rhythmic character were omitted from consideration.

27 Thus, a melodic section of a Serbo-Croatian folk song could be presented, for instance, as " $-2+2-2+2-2-2$ ".

28 "On the basis of this limited study, Early chant as opposed to Late chant can be said to be shorter, have more phrases, shorter phrases, be more limited in range (of notes), use smaller intervals, and have less shorter repeated patterns but more longer patterns." Joiner 1969, 213. 
rhythm. Among others, Mix discovered that the values of entropies of chords and pitches are much higher in Schoenberg's composition than in Haydn's. However, the relative 'contribution' of the rhythm to the total entropy is larger in Haydn's piece than in Schoenberg's. The dependencies among the parts are larger in Haydn's string quartet than in Schoenberg's. In a different experiment, Mix calculated entropies of pitches (up to order six) of the first violins of three Haydn quartets and compared them. But even though Mix's approaches represent great enhancements of information-theoretical analyses in their complex application to several musical parameters, his results were limited by the computer hardware. Methodically, Mix's approaches showed the limits of using only one measurement for comparative analyses. But while Fucks and Reckziegel (see ibid.) focussed on only one voice of multi-voice compositions, Mix had already attempted a 'vertical' analysis.

The East-German Reiner Kluge (1974) ${ }^{29}$ analyzed similarities among Altmark ${ }^{30}$ folk songs. More than 130 syntactic characteristics were discovered and then used to determine similarities of pairs of melodies (out of random samples with each about 40 melodies ${ }^{31}$. Kluge's research was outstanding, because he developed a similarity measurement, based on the formula $\mathrm{r}=-\cos \mathrm{A} / \mathrm{N}$, "whereby A is the number of the coincidences of two elements $\mathrm{j}, \mathrm{k}$ within $\mathrm{N}$ characteristics, relating to the totality of elements"32 (Kluge 1974, 31). Using factor analysis, Kluge identified pseudo-individuals, out of which 12 different types and mixed types were derived. The results of Kluge's analyses were limited in several ways:

- the hardware available for his research was too limited in speed and memory,

- the number of musical characteristics was not large enough,

- the definition of his measurement of similarity was insufficient,

- the criteria to describe melodic types were insufficient, and

- the number of random samples was too small.

However, Kluge's work became very valuable for further research in this area, because he found several characteristics and groups of characteristics as suitable for comparative analyses of folk songs. ${ }^{33}$ Furthermore, Kluge's study showed that a successful comparative analysis is only possible if many musical characteristics are analyzed in relation to each other.

\section{The Major Sources of Computer-Assisted Music Analysis of the 1960s}

Besides numerous articles, partly reviewed above, sources of computer-assisted music analysis of the 1960s include also three major publications on the use of com-

29 Even though his dissertation was published in 1974, the (dissertation) research was conducted between 1965 and 1968 , and defended in 1968

30. Altmark is an area in Southeastern Germany.

1 The restrictions to limited samples were necessary because of on the low efficiency of the computer used (ZRA1).

32 "... wobei A die Anzahl der Koinzidenzen zweier Individuen $\mathrm{j}, \mathrm{k}$ in N betrachteten Merkmalen in Bezug auf die betrachtete Individuengesamtheit ist."

33 Those valuable musical characteristics include, for instance, 'inner melody shape', 'melodic incipits', 'pitch repertory contains the leading tone', 'the lowest pitch occurs after the highest', 'number of changes of melodic direction in the first melodic line', 'unusual melodic intervals', 'unusual transition of tone durations', and 'time signature'. See Kluge 1974, 155-157. 
puters in music research - Heckmann 1967a, Lincoln 1970a, and Brook 1970a - each containing several analytical articles.

Harald Heckmann's book on "Elektronische Datenverarbeitung in der Musikwissenschaft" contained five articles on (computer-assisted) music analysis. George W. Logemann (1967), for instance, described a system for finding the positions in which the second voices of Bach canons from the Musical Offering begin; he tried all possible entry points and matched arising interval structures. Eric Regener (1967) introduced a transcription system as the basis for analytical research ${ }^{34}$; however, this system was not fully in operation at the time. Tobias D. Robison's (1967) article introduced IML-MIR, but did not include any practical application of MIR. Walter Reckziegel (1967) wrote on the use of measurements for inner tempo and individual tempo ${ }^{35}$, and Nanna Schiødt and Bjarner Svejgaard (1967) reported an analysis of Byzantine Sticherarion melodies. The latter project is of special importance and will be discussed here in more detail. It is of special importance, because it was, together with the research by Brender and Brender (1967; see above), one of the first projects of computer-assisted music analysis aimed at Medieval music. The task was to find musical formulas in Gregorian chant, whereby neumes were encoded with a special alphanumerical code. The computer program found all commonly used formulas, whereby the authors verified the results via conventional analytical methods. However, one of the most important results of this study relates to the proportion of expenditure to benefit. In most computer applications to music analysis - to this day - the coding and input process takes much too long, i.e. the proportion of expenditure to benefit is unsatisfactory. On the contrary, the analysis of Byzantine neumes seems to be much faster with the help of a computer: "After half an hour you have learned the code so well that you can type the code symbols a little faster than you can write the neumes out by hand. If you want to study the hymns 'by hand' they have to be written out in different ways in any case. Sometimes you may have to write them out in a new way for each new detail you want to study. Working with the computer you only need to write the hymns out once. Afterwards you put the punched paper tape in the machine and you can ask whatever question concerning the encoded material that might enter your mind. ..." (ibid., 194.)

Harry B. Lincoln's edition (1970a) of many papers on computer-assisted music analysis $^{36}$ include several statistical and combinatorial approaches to the analysis of atonal music. Mary E. Fiore (1970), Ramon Fuller (1970), and Roland Jackson (1970) made use of frequency counts of pitches, intervals, types of dissonances, and chord types (with a certain interval structure). Gerald Lefkoff (1970) analyzed twelve tone rows and computed the 48 permutations as well as similar segments within these permutations. A computer program by Ian Morton and John Lofstedt (1970) calculated frequencies of chordal roots (in tonal music) and their relation to certain beats of a measure. Joseph Youngblood (1970) tried to determine whether a composer's style is

34 His system was called SAM, "System for Analysis of Music", and was specifically written for the IBM 7090 computer. The transcription code used was LMT (Linear Music Transcription).

5 Thus, Reckziegel's research included further developments of his measurements; see Schüler 2005.

36 They all used either FORTRAN or SNOBOL as programming languages. 
characterized by the distribution of root progressions; mathematical measurements applied were frequency, probability, redundancy, and chi-square probability. However, the most important paper in Lincoln's volume with regard to computer-assisted music analysis was probably the paper on analyzing Javanese music by Fredric Lieberman (1970) ${ }^{37}$. This research is a classic example of dissatisfaction with results that are only partially acceptable. While the synthesis of Javanese-style melodies on the basis of analytical results retained by a 'nearest-neighbor Markov process' was not completely satisfactory, a complex system of interacting variables was developed, which could characterize Javanese music much better than just Markov chains by themselves. This complex system of variables included, among others, frequencies of pitches, transition frequencies of higher orders, and various (melodic) cadence forms. ${ }^{38}$

Barry S. Brook's book (1970a) is of importance in so far as it is a collection of papers presented at three Greater New York Chapter meetings ${ }^{39}$ of the American Musicological Society, two of which were on the topic "Musicology and the Computer". There, Allen Forte, Lewis Lockwood, Barry S. Brook, Murray J. Gould, and many others presented research on new developments in computer-assisted music analysis. ${ }^{40}$ These two conferences as well as the "West Virginia University Conference on Computer Applications in Music" in 1966 (Lefkoff 1967a) were the only conferences in the 1960s specifically on the topic of computer applications in music.

\section{Concluding Remarks}

A passage in Jan LaRue's article in the volume "Musicology 1960-2000" (Brook 1970 a) represents a common way of thinking during the 1960s in the area of computer-assisted music analysis: "May I recommend the computer to you as an instrument without human prejudices. It has its own prejudices, numerical and procedural. But these often act as stimulants and correctives, as healthy balances and supplements to human attitudes. With this new aid, the coming generation of musicologists should develop a style analysis that is comprehensive rather than selective, broad rather than personal, and rich in musical insight." (LaRue 1970, 197.) LaRue was certainly right in his implication that, at least up to the end of the 1960s, computer-assisted analysis of style was anything but comprehensive and rich in musical insight. Moreover, the goal of a comprehensive and inter-personal, computer-assisted analysis could not even be reached in the following decade.

37 See also Hood 1967.

38 Other articles in this volume (Lincoln 1970) referring to computer-assisted music analysis (in one way or the other) are by Frederick Crane and Judith Fiehler (1970), James Gabura (1970), Barton Hudson (1970), W. Earle Hultberg (1970), Theodore Karp (1970), and Michael Kassler (1970b).

39 Two meetings took place in 1965, and the third one in 1966.

40 This research has been discussed already earlier in this article. 


\section{Bibliography}

Babbitt, Milton. 1955. "Some Aspects of Twelve-Tone Composition," The Score and I.M.A. Magazine 12: 53-61.

Babbitt, Milton. 1960. "Twelve-Tone Invariants as Compositional Determinatns," The Music Quaterly 46: 246-259.

Babbitt, Milton. 1961. "Set-Structure as a Compositional Determinant," Journal of Music Theory V/1: 72-94.

Babbitt, Milton. 1965. "The Use of Computers in Musicological Research," Perspectives of New Music III/2: 74-83.

Baker, Robert Allen. 1963. A Statistical Analysis of the Harmonic Practice of the $18^{\text {th }}$ and Early $19^{\text {th }}$ Centuries. Ph.D. dissertation. University of Illinois.

Bauer-Mengelberg, Stefan. 1968. "The Truth, the Whole Truth, and Nothing but the Truth'," Computer Studies in the Humanities and Verbal Behavior I/2: 52-54.

Bauer-Mengelberg. 1970. "The Ford-Columbia Input Language," Musicology and the Computer: Three Symposia, ed. by Barry S. Brook. New York: The City University of New York Press. pp. 48-52.

Bean, Calvert. 1961. Information Theory Applied to the Analysis of a Particular Formal Process in Tonal Music. Ph.D. dissertation. University of Illinois.

Bernstein, Lawrence F. 1964. "Data Processing and the Thematic Index," Fontes Artis Musicae XI/1: 159-165.

Bernstein, Lawrence F. and Joseph P. Olive. 1969. "Computers and the $16^{\text {th }}$-century Chanson: A Pilot Project at the University of Chicago," Computers and the Humanities III/3 (January). pp. 153-160.

Brender, Maurita P., and Ronald F. Brender. 1967. "Computer Transcription and Analysis of Mid-Thirteenth Century Musical Notation," Journal of Music Theory XI/2 (Winter): 198-221.

Brook, Barry S. 1965a. "The Simplified 'Plaine and Easy Code System," Fontes Artis Musicae XII: 156-160.

Brook, Barry S. 1965b. "Utilization of Data Processing Techniques in Music Documentation," Fontes Artis Musicae 12 (May): 112-122.

Brook, Barry S. 1967. "Music Bibliography and the Computer," Papers from the West Virginia University Conference on Computer Applications in Music, ed. by Gerald Lefkoff. Morgantown: West Virginia University Library. pp. 9-27.

Brook, Barry S. 1969. "Style and Content Analysis in Music: The Simplified 'Plaine and Easy Code'," The Analysis of Communication Content, ed. by George Gerbner et al. New York: John Wiley \& Sons. pp. 287-296.

Brook, Barry S, ed. 1970a. Musicology and the Computer: Three Symposia. New York: The City University of New York Press.

Brook, Barry S. 1970b. "Music Documentation of the Future," Musicology and the Computer: Three Symposia, ed. by Barry S. Brook. New York: The City University of New York Press. pp. 28-36.

Brook, Barry S. 1970c. "The Plaine and Easie Code," Musicology and the Computer: Three Symposia, ed. by Barry S. Brook. New York: The City University of New York Press. pp. 53-56. 
Brook, Barry S., and Murray Gould. 1964. "Notating Music with Ordinary Typewriter Characters," Fontes Artis Musicae XI/1 (January-April): 142-159.

Brooks, Frederick P., A. L. Hopkins, P. G. Neumann, and W. V. Wright. 1957. "An Experiment in Musical Composition." IRE Transactions on Electronic Computers VI: 175-182. (An errata see in vol. 7 (1958): 60.) Reprinted in Machine Models of Music, ed. by Stephen M. Schwanauer and David A. Levitt. Cambridge, MA: The MIT Press, 1993. pp. 23-40.

Crane, Frederick. 1968. "Statistical Comparison of Musical Styles," Computers and the Humanities II/5: 244.

Crane, Frederick, and Judith Fiehler. 1970. "Numerical Methods of Comparing Musical Styles," The Computer and Music, ed. by Harry B. Lincoln. Ithaca: Cornell University Press. pp. 209-222.

Fiore, Mary E. 1968. "Harmonic Structure in Variation Movements by Webern," Computers and the Humanities II/5: 243.

Fiore, Mary E. 1970. "Webern's Use of Motive in the Piano Variations," The Computer and Music, ed. by Harry B. Lincoln. Ithaca: Cornell University Press. 115-122.

Forte, Allen. 1966. "A Program for the Analytic Reading of Scores," Journal of Music Theory X/2 (Winter): 330-364. Reprinted in Machine Models of Music, ed. by Stephen M. Schwanauer and David A. Levitt. Cambridge, MA: The MIT Press, 1993. 55-81.

Forte, Allen. 1967a. "Computer-implemented Analysis of Musical Structure," Papers from the West Virginia University Conference on Computer Applications in Music, ed. by Gerald Lefkoff. Morgantown: West Virginia University Library. 29-42.

Forte, Allen. 1967b. "Music and Computing: The Present Situation," Computers and the Humanities II/1: 32-35.

Forte, Allen. 1970a. "The Domain and Relations of Set-Complex Theory," Journal of Music Theory IX/1: 173-180.

Forte, Allen. 1970b. "The Structure of Atonal Music: Practical Aspects of a Computer-Oriented Research Project," Musicology and the Computer: Three Symposia, ed. by Barry S. Brook. New York: The City University of New York Press. 10-18.

Fuller, Ramon Conrad. 1965. An Information Theory Analysis of Anton Webern's 'Symphonie,' opus 21 (with) 'Music for Two Channel Tape and Two Percussionists'. D.M.A. dissertation. University of Illinois at Urbana Champaign.

Fuller, Ramon Conrad. 1970. "Toward a Theory of Webernian Harmony, via Analysis with a Digital Computer," The Computer and Music, ed. by Harry B. Lincoln. Ithaca: Cornell University Press. pp. 123-131.

Gabura, A. James. 1965. "Computer Analysis of Musical Style," Association of Computing Machinery Proceedings of the 20 th National Conference. New York: Association for Computing Machinery.

Gabura, A. James. 1967. Music Style Analysis by Computer. M.Sc. thesis, University of Toronto.

Gabura, A. James. 1970. "Musical Style Analysis by Computer," The Computer and Music, ed. by Harry B. Lincoln. Ithaca: Cornell University Press. pp. 223-276.

Heckmann, Harald. 1964. "Neue Methoden der Verarbeitung musikalischer Daten," Die Musikforschung XVII/4: 381-383. 
Heckmann, Harald, ed. 1967a. Elektronische Datenverarbeitung in der Musikwissenschaft. Regensburg: Gustav Bosse.

Heckmann, Harald. 1967b. "Elektronische Datenverarbeitung in der Musikwissenschaft. Eine Einleitung," Elektronische Datenverarbeitung in der Musikwissenschaft, ed. by Harald Heckmann. Regensburg: Gustav Bosse. pp. VII-XVII.

Heckmann, Harald. 1970. "Elektronische Datenverarbeitung in der Musikwissenschaft," IMS: Report on the Tenth Congress, Ljubljana 1967, ed. by Dragotin Cvetko. Kassel: Bärenreiter, 1970. pp. 424-427.

Hiller, Lejaren A., Jr. 1962. Information Theory and Musical Analysis. Mimeographed. Urbana: University of Illinois, Experimental Music Studio. Technical Report No. 5, July 1962. 40 p. (University of Cincinnati Library, MUS ML 3817 .I4 no. 5).

Hiller, Lejaren A., Jr. 1964. Informationstheorie und Computermusik. Darmstädter Beiträge zur Neuen Musik 8. Mainz: B. Schott's Söhne.

Hiller, Lejaren A., and Calvert Bean. 1966. "Information Theory Analyses of Four Sonata Expositions," Journal of Music Theory X: 96-137.

Hiller, Lejaren A., and James W. Beauchamp. 1968. Review of Completed and Proposed Research on Analysis and Synthesis of Musical Sounds by Analog and Digital Techniques. Technical Report No. 19. Urgana, IL: University of Illinois, Experimental Music Studio.

Hiller, Lejaren A., and Ramon Fuller. 1967. "Structure and Information in Webern's Symphonie, Op. 21," Journal of Music Theory XI/1: 60-115.

Hiller, Lejaren A., and Leonard M. Isaacson. 1959. Experimental Music. Composition with an electronic computer. New York: McGraw-Hill.

Hindemith, Paul. 1945. The Craft of Musical Composition, translated by Arthur Mendel. rev. ed. New York: Associated Music Publishers.

Hood, Mantle. 1967. "Improvisation and Music Theory of the Javanese Gamelan," Computers and the Humanities II/2: 88.

Hudson, Barton. "Toward a Comprehensive French Chanson Catalog," The Computer and Music, ed. by Harry B. Lincoln. Ithaca: Cornell University Press. pp. 277-287.

Hultberg, W. Earle. 1970. "Transcription of Tablature to Standard Notation," The Computer and Music, ed. by Harry B. Lincoln. Ithaca: Cornell University Press. pp. 289-292.

Jackson, Roland. 1966. "Harmonic Analysis," Computers and the Humanities I/2: 52.

Jackson, Roland. 1970a. "Harmony before and after 1910: A Computer Comparison," The Computer and Music, ed. by Harry B. Lincoln. Ithaca: Cornell University Press. pp. 132-146.

Jackson, Roland. 1970b. "The Computer as a 'Student' of Harmony," IMS: Report on the Tenth Congress, Ljubljana 1967, ed. by Dragotin Cvetko. Kassel: Bärenreiter. pp. 435-440.

Jackson, Roland, and Philip Bernzott. 1966. "Harmonic Analysis with Computer-A Progress Report," ICRH Newsletter I/9: 3-4.

Jackson, Roland, and Philip Bernzott. 1970. "A Musical Input Language and a Sample Program for Musical Analysis," Musicology and the Computer: Three Symposia, ed. by Barry S. Brook. New York: The City University of New York Press. pp. 130-150. 
Joiner, Richard E. 1969. "Gregorian Chant," Computer Studies in the Humanities and Verbal Behavior II/4 (December): 213-219.

Karp, Theodore. 1970. "A Test for Melodic Borrowings among Notre Dame Organa Dupla," The Computer and Music, ed. by Harry B. Lincoln. Ithaca: Cornell University Press. pp. 293-295.

Kassler, Michael. 1964a. A Report of Work, Directed Toward Explication of Schenker's Theory of Tonality, Done in Summer 1962 as the First Phase of a Project Concerned with the Applications of High-Speed Automatic Digital Computers to Music and Musicology. Princeton, N.J.: Princeton University Music Department. (Mimeographed.)

Kassler, Michael. 1964b. MIR - A Simple Programming Language For Musical Information Retrieval. Technical Report No. 3, Project 295D, March 1964. Princeton, New Jersey: Princeton University, Department of Music. [University of California at Berkeley: Music Library, calling no. ML 74.4 M4 K 351964 MUSI]

Kassler, Michael. 1966. "Toward Musical Information Retrieval," Perspectives of New Music IV/2 (Spring-Summer): 59-67.

Kassler, Michael. 1968. A Trinity of Eassays. Ph.D. dissertation, Princeton University.

Kassler, Michael. 1969. Review of Kibernetika i muzyka by R. Kh. Zaripov, Perspectives of New Music VII/2: 115.

Kassler, Michael. 1970a. "An Essay toward Specification of a Music-Reading Machine," Musicology and the Computer: Three Symposia, ed. by Barry S. Brook. New York: The City University of New York Press. 151-175.

Kassler, Michael. 1970b. "MIR-A Simple Programming Language for Musical Information Retrieval," The Computer and Music, ed. by Harry B. Lincoln. Ithaca: Cornell University Press. 299-327.

Kluge, Reiner. 1967. "Faktorenanalytische Typenbestimmung an einstimmigen Volksmelodien," Computers and the Humanities II/2: 88-89.

Kluge, Reiner. 1970a. "Volksliedanalyse und -systematisierung mit Hilfe eines Rechenautomaten," Bericht über den Internationalen Musikwissenschaftlichen Kongress Leipzig 1966, ed. by Carl Dahlhaus et al. Kassel: Bärenreiter. pp. 158-465.

Kluge, Reiner. 1970b. "Zur Automatischen Quantitativen Bestimmung Musikalischer Ähnlichkeit," IMS: Report on the Tenth Congress, Ljubljana 1967, ed. by Dragotin Cvetko. Kassel: Bärenreiter, 1970. pp. 450-457.

Kluge, Reiner. 1974. Faktorenanalytische Typenbestimmung an Volksliedmelodien. Beiträge zur musikwissenschaftlichen Forschung in der DDR 6. Leipzig: Deutscher Verlag für Musik.

Kostka, Stephan M. 1969. The Hindemith String Quartets: A Computer-Assisted Study of Selected Aspects of Style. Ph.D. dissertation, University of Wisconsin.

Kostka, Stephan M. 1971. "Recent Developments in Computer-Assisted Musical Scholarship," Computers and the Humanities VI/1 (September): 15-21.

Kostka, Stephan M. 1974. A bibliography of computer applications in music. Hackensack, N.J.: J. Boonim.

Kostka, Stephan M. 1984. "The M-PARC system for musical encoding (Mnemonic pitch and rhythm code, version 3)." Unpublished Manuscript, The University of Texas at Austin, Department of Music, Austin. 
LaRue, Jan. 1970. "New Directions for Style Analysis," Musicology and the Computer: Three Symposia, ed. by Barry S. Brook. New York: The City University of New York Press. pp. 194-197.

Lefkoff, Gerald, ed. 1967a. Papers from the West Virginia University Conference on Computer Applications in Music. Morgantown: West Virginia University Library.

Lefkoff, Gerald. 1967b. "Computers and the Study of Musical Style," Papers from the West Virginia University Conference on Computer Applications in Music, ed. by Gerald Lefkoff. Morgantown: West Virginia University Library. pp. 43-61.

Lefkoff, Gerald. 1970. "Automated Discovery of Similar Segments in the Forty-eight Permutations of a Twelve-Tone Row," The Computer and Music, ed. by Harry B. Lincoln. Ithaca: Cornell University Press. pp. 147-153.

Lieberman, Fredric. 1970. "Computer-Aided Analysis of Javanese Music," The Computer and Music, ed. by Harry B. Lincoln. Ithaca: Cornell University Press. pp. 181-192.

Lincoln, Harry B. 1966. "Incipit Interval Sequence Program," Computers and the Humanities I/2: 52.

Lincoln, Harry B. 1967a. "Musicology and the Computer: The Thematic Index," Computers in Humanistic Research, ed. by Edmund A. Bowles. Englewood Cliffs: Prentice Hall. pp. 184-193.

Lincoln, Harry B. 1967b. "Some Criteria and Techniques for Developing Computerized Thematic Indices," Elektronische Datenverarbeitung in der Musikwissenschaft, ed. by Harald Heckmann. Regensburg: Gustav Bosse. pp. 57-62.

Lincoln, Harry B. 1967c. "Thematic Index of Sixteenth-Century Italian Music," Computers and the Humanities II/2: 86.

Lincoln, Harry B. 1968a. "The Thematic Index: A Computer Application to Musicology," Computers and the Humanities 2 (1967-68): 215-220.

Lincoln, Harry B. 1968b. Development of Computerized Techniques in Music Research with Emphasis on the Thematic Index. Washington: Office of Education, U.S. Department of Health, Education, and Welware. 39 p. ERIC No. ED 027609.

Lincoln, Harry B. 1968c. "Thematic Index of Sixteenth-Century Italian Music," Computers and the Humanities II/5: 243.

Lincoln, Harry B. 1969a. "A Computer Application in Musicology: The Thematic Index," Information Processing 68. Proceedings of the IFIP Congress 1968, ed. by A. J. H. Morrel. Amsterdam: North Holland. pp. 957-961.

Lincoln, Harry B. 1969b. Development of Computerized Techniques in Music Research with Emphasis on the Thematic Index. Washington: Office of Education, U.S. Department of Health, Education, and Welware. 15 p. ERIC No. ED 041031.

Lincoln, Harry B, ed. 1970a. The Computer and Music. Ithaca: Cornell University Press.

Lincoln, Harry B. 1970b. "The Current State of Music Research and the Computer," Computer and the Humanities V/1: 29-36.

Lincoln, Harry B. 1970c. "Thematic Indexing by Computer, Including Development of Necessary Hardware to Permit Printing of Music by Computer," Computers and the Humanities V/2: 109-110.

Lincoln, Harry B. 1970d. A Study of Computer Techniques for Music Research. Final Report. Washington: Office of Education, U.S. Department of Health, Education, and Welware. ERIC No. ED 043650. 
Lockwood, Lewis. 1966. "MIR ('Musical Information Retrieval')," Computers and the Humanities I/2: 51.

Lockwood, Lewis. 1970a. "A Stylistic Investigation of the Masses of Josquin Desprez with the Aid of the Computer: a Progress Report," Musicology and the Computer: Three Symposia, ed. by Barry S. Brook. New York: The City University of New York Press. pp. 19-27.

Lockwood, Lewis. 1970b. "Computer Assistance in the Investigation of Accidentals in Renaissance Music," IMS: Report on the Tenth Congress, Ljubljana 1967, ed. by Dragotin Cvetko. Kassel: Bärenreiter, 1970. pp. 444-449.

Logemann, George W. 1966a. "Prepare Music Input Data," Computers and the Humanities I/2: 51 .

Logemann, George W. 1966b. "Harmonic and Time-line Input and Statistics," Computers and the Humanities I/2: 51-52.

Logemann, George W. 1967. "The Canons in the Musical Offering of J. S. Bach: An Example of Computational Musicology," Elektronische Datenverarbeitung in der Musikwissenschaft, ed. by Harald Heckmann. Regensburg: Gustav Bosse. 63-87.

Mendel, Arthur. 1969. "Some Preliminary Attempts at Computer-Assisted Style Analysis in Music," Computers and the Humanities IV/1 (September): 41-52.

Mix, Roland. 1967. "Die Entropieabnahme bei Abhängigkeit zwischen mehreren simultanen Informationsquellen und bei Übergang zu Markoff-Ketten höherer Ordnung, untersucht an musikalischen Beispielen," Theorien zur Formalanalyse mehrstimmiger Musik, by Walter Reckziegel. Köln: Westdeutscher Verlag. pp. 39-80.

Morton, Ian A. 1967. "FORTRAN Music Programs Involving Numerically Related Tones," Computers and the Humanities II/2: 87-88.

Morton, Ian, and John Lofstedt. 1970. "FORTRAN Music Programs Involving Numerically Related Tones," The Computer and Music, ed. by Harry B. Lincoln. Ithaca: Cornell University Press. pp. 154-162.

Paisley, William J. 1964. "Identifying the Unknown Communicator in Painting, Literature and Music: the Significance of Minor Encoding Habits," Journal of Communication XIV/4: 219-237.

Paisley, William J. 1969. "Studying 'Style' as deviation from encoding norms," The Analysis of Communication Content. Developments in Scientific Theories and Computer Techniques, ed. by George Gerbner, Ole R. Holsti, Klaus Krippendorff, William J. Paisley and Philip J. Stone. New York: Wiley \& Sons. pp. 133-146.

Pederson, Donald Margedo. 1968. Some Technique for Computer-Aided Analysis of Musical Scores. Ph.D. dissertation, The University of Iowa.

Regener, Eric. 1967a. "A Multiple-pass Transcription and a System for Music Analysis by Computer," Elektronische Datenverarbeitung in der Musikwissenschaft, ed. by Harald Heckmann. Regensburg: Gustav Bosse. pp. 89-102.

Regener, Eric. 1967b. "Layered Music-Theoretic Systems," Perspectives of New Music 5: 52-62.

Robison, Tobias D. n.d. "A Short Description of the MIR Compiler," Princeton: Princeton University Music Department. n.d. 
Robison, Tobias D. 1967. "IML-MIR: A Data-Processing System for the Analysis of Music," Elektronische Datenverarbeitung in der Musikwissenschaft, ed. by Harald Heckmann. Regensburg: Bosse. pp. 103-135.

Schiodt, Nanna, and Bjarner Svejgaard. 1967. "Application of Computer Technique to the Analysis of Byzantine Sticherarion Melodies," Elektronische Datenverarbeitung in der Musikwissenschaft, ed. by Harald Heckmann. Regensburg: Gustav Bosse. pp. 187-201.

Schüler, Nico. 1996. "Methoden Computerunterstützter Musikanalyse - ein historischer Überblick," Zum Problem und zu Methoden von Musikanalyse, ed. by N. Schüler. Hamburg: von Bockel, 1996. pp. 51-76.

Schüler, Nico. 2000. Methods of Computer-Assisted Music Analysis: History, Classification, and Evaluation. Ph.D. dissertation. East Lansing: Michigan State University.

Schüler, Nico. 2002. "The Philosophical Rationale of Computer-Assisted Music Analysis: Information Theory and Aesthetics," Computer-Applications in Music Research: Concepts, Methods, Results, ed. by Nico Schüler. Frankfurt: Peter Lang, 2002. pp. 19-30.

Schüler, Nico. 2005. "Reflections on the History of Computer-Assisted Music Analysis I: Predecessors and the Beginnings," Musicological Annual XXXXI/1: 31-43.

Schüler, Nico. 2006. "Towards a History and Evaluation of Statistical and Information-Theoretical Analysis of Melodic Incipits," Theoria: Historical Aspects of Music Theory 13: 113-126.

Suchoff, Benjamin. 1967a. "Computer Applications to Bartók’s Serbo-Croatian Material," Tempo 80 (Spring): 15-19.

Suchoff, Benjamin. 1967b. "Computer Applications to Béla Bartók's Serbo-Croatian Material," Computers and the Humanities II/2: 88.

Suchoff, Benjamin. 1968a. "Bartók, Ethnomusicology, and the Computer," Institute for Computer Research in the Humanities Newsletter IV/4 (December): 3-6.

Suchoff, Benjamin. 1968b. "Computerized Folk Song Research and the Problem of Variants," Computers and the Humanities II/4 (March): 155-158.

Suchoff, Benjamin. 1969. "Some Problems in Computer-Oriented Bartokian Ethnomusicology,” Ethnomusicology XIII/3: 489-497.

Suchoff, Benjamin. 1970a. "Computer-Oriented Comparative Musicology," The Computer and Music, ed. by Harry B. Lincoln. Ithaca: Cornell University Press. 193-206.

Suchoff, Benjamin. 1970b. "Studies Rekating to Automation of Bartók Archives," Computers and the Humanities V/2: 110.

Suchoff, Benjamin. 1970c. "Aplicarea calculatorelor elektronice la etnomuzicologia Bartokiana," Musica XI (November): 10-14.

Suchoff, Benjamin. 1970d. "A Bartoki nepzenekutatas es az elektronikus szamitogepeg,” Muzsika XIII (July): 6-8; (August): 4-6.

Suchoff, Benjamin. 1971a. "Studies Relating to Automatization of Bartók Archives," Computers and the Humanities V/5: 309-310.

Suchoff, Benjamin. 1971b. "The Computer and Bartók Research in America," Journal of Research in Music Education XIX/1 (Spring): 3-16.

Youngblood, Joseph E. 1958. "Style as Information." Journal of Music Theory II: 24-35. 
Youngblood, Joseph E. 1960. Music and language: some related analytical techniques. Ph.D. thesis, Indiana University.

Youngblood, Joseph E. 1967. "Root Progression and Composer Identification," Computers and the Humanities II/2: 87.

Youngblood, Joseph E. 1970. "Root Progressions and Composer Identification," The Computer and Music, ed. by Harry B. Lincoln. Ithaca: Cornell University Press. pp. 172-178.

\section{Povzetek}

Gre za drugi v vrsti člankov o zgodovini računalniške analize glasbe. Članek najprej poda kratek pregled razvoja računalništva $\mathrm{v}$ šestdesetih letih, pri čemer izpostavlja dejstvo, da je - v nasprotju $s$ pomenom računalnikov in računalništva $v$ industriji in vojski - bila uporaba računalnikov v raziskovalne namene $\mathrm{v}$ glasbi $\mathrm{v}$ šestdesetih letih zelo omejena tako glede števila računalnikov na velikih univerzah kot tudi zavoljo njihovih tehnološko omejenih zmožnosti. Medtem ko razpravlja o razvojno najpomembnejših pristopih in prispevkih - ki so jih napisali William J. Paisley, Stefan M. Kostka, Donald M. Pederson, Lawrence F. Bernstein in Joseph P. Olive,
Benjamin Suchoff, Maurita P. Brender in Ronald F. Brender, Michael Kassler, Richard E. Joiner, Ian Morton in John Lofstedt, Mary E. Fiore, Ramon Fuller, Roland Jackson, Nanna Schiødt in Bjarner Svejgaard, Roland Mix, Reiner Kluge, Gerald Lefkoff, Fredric Lieberman in drugi - članek ugotavlja, da je vse do konca šestdesetih računalniška analiza bila vse prej kot izčrpna, medosebno povezana ter glede svojih vpogledov bogata. Kljub temu pa je prav bogastvo poizkusov računalniške analize v šestdesetih, pri čemer so bile večinoma uporabljene statistične in informacijsko-teoretične metode za analizo nezahodne in tudi zahodne ljudske in umetne glasbe, zagotovilo podlago za bolj poglobljene načine računalniške analize glasbe v naslednjih desetletjih. 